\title{
Transconjunctival medial anterior orbitotomy for the removal of a wooden intraorbital foreign body extending to the optic nerve: A
} case report

\author{
Optik sinire uzanım gösteren tahta bir yabancı cismin transkonjonktival medial \\ anterior orbitotomi ile çıkarılması: Bir olgu sunumu
}

\author{
Meryem Altın Ekin ${ }^{1}$, Şeyda Karadeniz Uğurlu ${ }^{1}$
}

\begin{abstract}
Intraorbital foreign bodies can be classified into organic or inorganic according to their chemical composition. Wooden is inorganic in nature and is a rare, but serious form of intraorbital foreign body injuries. Evaluation and management of intraorbital wooden foreign bodies are highly challenging and can lead to severe orbital complications. In this paper, we report a case of a 33-year old man who presented with a penetrating wooden foreign body injury to the left orbit. Computed tomography revealed a linear shaped foreign body extending from left supraorbital ridge to the intraconal area. The tip of the foreign body was touching to the optic nerve without disrupting its integrity. The patient underwent transconjunctival medial anterior orbitotomy and the wooden foreign body was found to be located close proximity to the optic nerve in intraconal space. A $7 \mathrm{~cm}$ wooden stick was removed completely with controlled traction. Postoperative recovery was uneventful with normal ophthalmic examination. Transconjunctival medial anterior orbitotomy is a useful and effective method for the removal of intraorbital wooden foreign bodies located in intraconal space.
\end{abstract}

Key words: wooden foreign body, intraconal, intraorbital, optic nerve, orbitotomy

\begin{abstract}
Öz
İntraorbital yabancı cisimler kimyasal içeriklerine göre organik ve inorganik olarak sınıflandırılabilirler. Tahta inorganik yapıda ve intraorbital yabancı cisim yaralanmalarının nadir fakat şiddetli bir formudur. İntraorbital tahta yabancı cisim yaralanmalarının değerlendirilmesi ve yönetimi oldukça zordur ve ciddi orbital komplikasyonlara yol açabilir. Bu yazıda, otuz-üç yaşındaki erkek hastanın sol orbitasına tahta bir yabancı cisim ile olan penetran yaralanmasını sunuyoruz. Bilgisayarlı tomografi ile sol supraorbital bölgeden intrakonal bölgeye uzanım gösteren doğrusal bir yabancı cisim görüntülendi. Yabancı cismin ucu optik sinire yapısal bütünlüğünü bozmadan temas etmekteydi. Hastaya transkonjonktival medial anterior orbitotomi uygulandı ve tahta yabancı cisim intrakonal bölgede optik sinire çok yakın lokalize olarak bulundu. Kontrollü traksiyonla 7 cm'lik bir tahta parçası tamamen çıkartıldı. Postoperatif dönem normal oftalmik muayeneyle sorunsuzdu. Transkonjonktival medial anterior orbitotomi intrakonal bölgelerdeki tahta yabancı cisimlerin çıkartılması için kullanışlı ve etkili bir yöntemdir.
\end{abstract}

Anahtar Kelimeler: tahta yabancı cisim, intrakonal, intraorbital, optik sinir, orbitotomi
${ }^{1}$ Katip Celebi University, Ataturk Education and Research Hospital, Department of Ophthalmology, Izmir, Turkey.

Informed Consent: The written consent was received from the patient who was presented in this study.

Hasta Onamı: Çalıșmada sunulan hastadan yazılı onam alınmıştır.

Conflict of Interest: No conflict of interest was declared by the authors.

Çıkar Çatışması: Yazarlar çıkar çatıșması bildirmemişlerdir.

Financial Disclosure: The authors declared that this case has received no financial support.

Finansal Destek: Yazarlar bu olgu için finansal destek almadıklarını beyan etmişlerdir.

Geliş Tarihi / Received: 22.02.2019

Kabul Tarihi / Accepted: 29.03.2019

Yayın Tarihi / Published: 01.08.2019

Sorumlu yazar / Corresponding author Meryem Altın Ekin

Adres/Address: Department of Ophthalmology, Izmir Katip Celebi University Ataturk Training and Research Hospital, Izmir, Turkey

e-mail: meryemekin@hotmail.com Tel/Phone: +90 2323293535

Copyright (C) ACEM 


\section{Introduction}

Penetrating intraorbital foreign body injuries occur with one sixth of orbital traumas [1]. Intraorbital foreign bodies are most commonly caused by inorganic objects including metallic and non-metallic materials. Wooden is inorganic in nature and is a rare, but serious form of intraorbital foreign body injuries. It is very difficult to identify quantity and composition of wooden foreign bodies within the orbital tissue by radiological imaging techniques. Wooden foreign bodies have many pores on their surface which may serve as a nidus for bacteria. Compared with metallic ones, surgical removal of wooden foreign bodies in one piece is much more challenging due to the risk of fragmentation. Wooden foreign bodies may get retained in orbit and result in wide range of complications like abscess, cellulitis, fibrosis, functional and visual deficits [2]. Therefore, organic foreign bodies like wooden remain an important diagnostic and therapeutic problem. Due to the danger of functional and visual disorders, intraorbital wooden foreign bodies are to be removed as early as possible. Furthermore, lesions located in intraconal space are especially difficult to manage. Surgical complications of orbit are highest if the lesion is in the intraconal space [3]. However, the number of cases regarding management of intraconal wooden foreign bodies are limited [4-6].

In this unusual case, we described a successful surgical approach to an intraconal wooden foreign body extending to optic nerve.

\section{Case report}

A 33-year old man presented to the emergency department with an injury to his left orbit. Sixteen hours earlier, he had a head trauma in a motorcycle accident. On physical examination, a wooden stick was protruding out from the medial border of supraorbital ridge, appearing to be lodged deep within the orbit (Figure 1). There was no active bleeding from entry site and the patient was neurologically stable. Ophthalmic examination revealed lid edema and conjunctival hyperemia. His pupillary light reflex and color vision were normal. Ocular movements were free in all directions. Best corrected visual acuity of left eye was 10/10 with Snellen chart. Examination of the anterior and posterior segments was normal. Ophthalmic examination of his right eye was unremarkable.

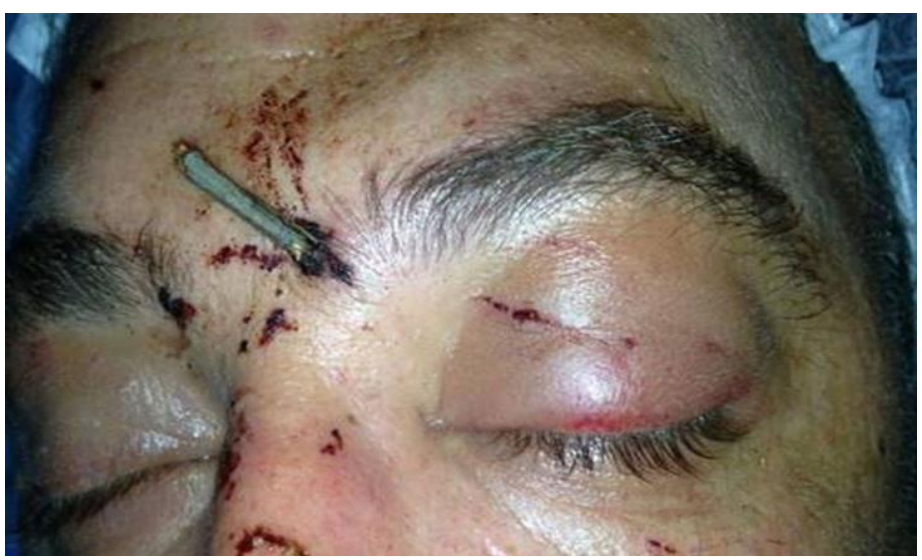

Figure 1.Wooden foreign body protruding from left medial supraorbital ridge.

Computed tomography (CT) that was performed upon admission revealed a linear shaped, well delineated foreign body as low density relative to surrounding orbital fat, which mimicked air bubbles (Figure 2).
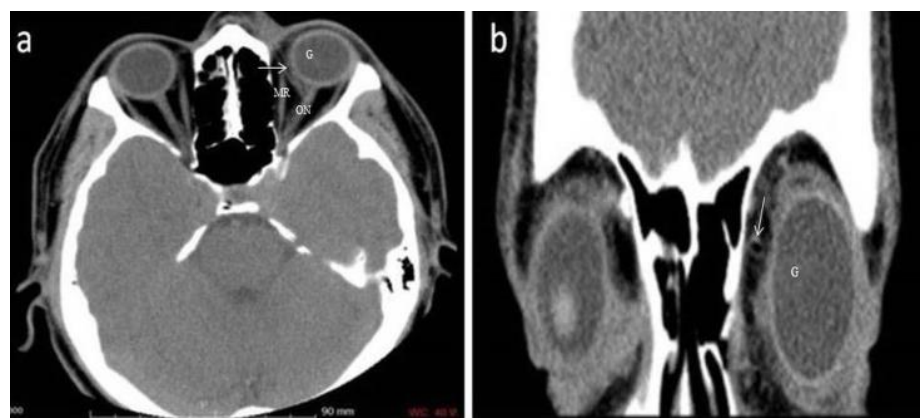

Figure 2. a, b: (a) Axial computed tomography scan showing linear shaped, air mimicked foreign body (white arrow) extending to the left intraconal space (G: globe, MR: the medial rectus muscle, ON: optic nerve). (b) Coronal computed tomography scan showing air density (white arrow) in the left retrobulbar area (G: globe).

The foreign body was measuring $7 \mathrm{~cm}$ in length and breaking through medial side of the left orbit, proceeding along the left medial orbital wall and stopping at the left retrobulbar area. The tip of the structure was touching to the optic nerve without disrupting its integrity. The foreign body was not causing any deviation of the globe. There was no fracture in orbital bones and intracranial penetration was not observed.

A single $2 \mathrm{~g}$ dose of cefazoline was administered for prophylaxis. Transconjunctival medial anterior orbitotomy was considered the treatment of choice for removal of foreign body (Figure 3a). After spreading the eyelids apart under general anesthesia, a vertical incision line is marked on the upper eyelid at the junction of the medial one third and the lateral two thirds of the lid. The line was incised with a scalpel blade and extended full thickness along the eyelid with Stevens scissors. A 180 degree conjunctival peritomy was performed at the medial limbus. To improve exposure, radial relaxing incisions were made to the bulbar conjunctiva. Stevens scissors was used to bluntly separate the Tenon's capsule from sclera. Bleeding points sealed by diathermy coagulation. The conjunctiva was then retracted and a traction suture is then placed under the medial rectus muscle to guide the globe in the desired direction to reach the retrobulbar space. Medial rectus muscle was disinserted completely from its insertion. The intraconal space was entered through Tenon's capsule with Sewell and 1/4 inch malleable retractors. The wooden foreign body was palpated just above the medial rectus muscle, lying next to the optic nerve. Optic nerve was found to be intact. The wooden stick was removed completely by grasping the tip with two fingers, and slowly pulling out with rotating movements (Figure $3 b$ ).
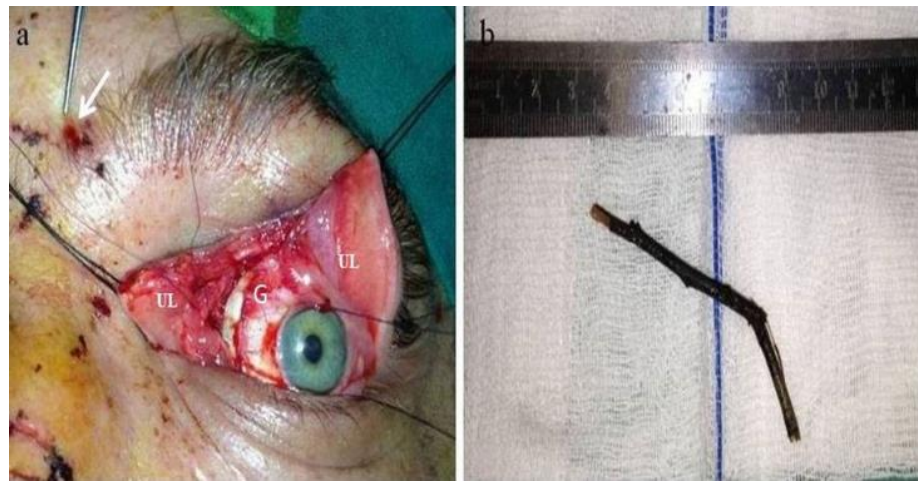

Figure 3. a, b : ((a) Intraoperative view of transconjunctival medial anterior orbitotomy. White arrow indicates entry site of foreign body (G: globe, UL: upper lid). (b) A wooden foreign body of $7 \mathrm{~cm}$ in length was removed from intraconal space. 
Medial rectus muscle was sewn back on the globe and the conjunctiva was closed with absorbable sutures. Postoperatively, the patient was put on systemic broad spectrum antibiotics (clindamycin 4x600 $\mathrm{mg}$ and voriconazole 2x6 mg/kg). A microbiologic culture obtained from the wound revealed Staphylococcus epidermidis. Magnetic resonance imaging (MRI) after surgery showed postoperative changes along the tract of foreign body and did not reveal any hematoma, retained foreign body or abscess. The postoperative course was uneventful, and he was discharged without neurologi $\neg$ cal deficits. On postoperative day 7 , the visual acuity measured 10/10. Incision was well healed with normal lid position. Eye movements were free to all directions (Figure 4).

Informed consent was obtained from the patient.

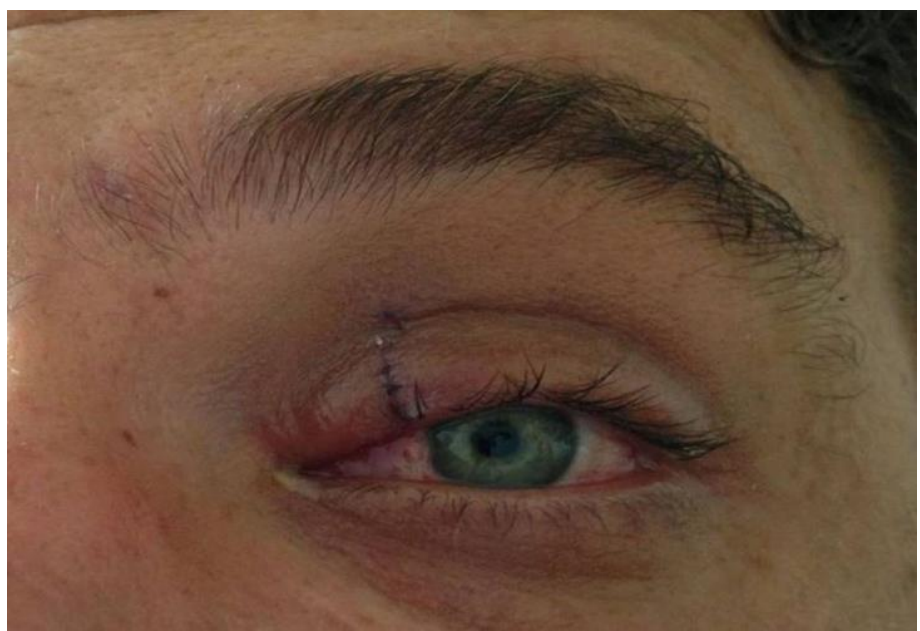

Figure 4. Early postoperative image of the patient.

\section{Discussion}

Orbital foreign bodies can cause a spectrum of presentations, from minimal symptoms to severe morbidity. Ocular manifestations of intraorbital foreign bodies mainly result from muscle impingement in fractured bones in the orbital walls or trauma to the trochlear, oculomotor or abducens nerve. Conical shape of the orbital cavity can cause penetrating injuries of ophthalmic vessels, cavernous sinus or optic nerve by directing foreign bodies toward the orbital apex. The orbital roof and apex have relatively thin bones that decrease resistance to cranial vault. Intraorbital foreign bodies can be classified into organic or inorganic according to their chemical composition. Most of the orbital foreign bodies are inorganic materials which are typically plastic, metallic or glass. Wooden is a type of organic foreign bodies.

Penetrating wooden orbital foreign bodies are difficult to evaluate clinically and mismanagement can lead to disastrous sequela for the orbital contents and even the brain. Management of intraorbital wooden foreign bodies are challenging for several reasons. Intraorbital wooden foreign bodies differ from inorganic foreign bodies, where retention of deep and small foreign bodies can be watched expectantly unless they cause functional impairment [7]. Unlike metal, plastic or glass, organic foreign bodies, such as wood carry high risk of infection and require removal as soon as possible. Even routine antibiotic use, infection rates of up to $64 \%$ with intraorbital wooden foreign bodies have been reported [8]. This is because infectious agents can easily attach to rough surface of wooden foreign bodies which acting as a potential nidus. Therefore, it is generally recommended to remove intraorbital wooden foreign bodies due to increased risk for infection and inflammation. In addition, infections due to retained intraorbital wooden foreign bodies may lead to abscess, panophthalmitis and fistula complications [5, 8].

Physical examination often underestimates the severity of injury and therefore, radiological investigations are mandatory. Radiological images assist in determining the integrity of the globe, proper localization of the foreign body, estimation of its shape, size and consistency and the relation to the adjacent orbital tissue. Nature of foreign body should be considered in the choice of imaging modality. Radiological imaging of intraorbital wooden foreign bodies can be performed using several different techniques. Standard radiography could not detect wooden foreign bodies in the orbit. Ultrasound has limited diagnostic value in some cases due to its availability and experience of the sonographer. Therefore, a CT scan is usually preformed in such cases. Numerous reports have demonstrated that CT is currently the imaging modality of choice for wooden intraorbital foreign bodies [2, 5, 8]. Serial imaging including axial, coronal and parasagittal views are required to maximally assess the superior orbital fissure and orbital roof. CT success in detection of intraorbital wood depends on extent of collateral inflammation, the location of the wood, incorporation of radiopaque substance and degree of wood hydration. The density of intraorbital wooden foreign bodies may change over time and the diagnosis is closely related to time of injury. In the subacute stage, it may be difficult to distinguish from surrounding orbital fat. In acute stages, wooden foreign bodies usually present as hypoattenuating on CT images; because of their low attenuation, they mimicked air bubbles, as revealed in our case. With the help of $\mathrm{CT}$, we initially interpreted that proximal end of the foreign body extended to the level of optic nerve. MRI was shown to be superior to CT in detecting the smallest pieces of wood [9]. It is believed that MRI could detect intraorbital wooden foreign bodies, even when CT findings are negative [9]. In this case, we performed a CT scan instead of MRI because possibility of metal foreign bodies could not be excluded in open injuries.

Intraorbital wooden foreign bodies should be timely treated with the best surgical approach according to foreign body size, location and injured area. It should be noted that removal from intraorbital localizations, particularly from intraconal space is challenging. Because, surgery of foreign body in intraconal region carries an increased risk for motility disorders and optic neuropathy. Purgason and Hornblass pointed out that complication rate of orbital surgeries are highest when the lesion is in the intraconal region [10]. Therefore, blind intraorbital exploration should be discouraged. Surgical approach for intraorbital foreign body removal could be managed by exploring from entry site or through fistula pathway. Surgical access to intraconal region could be performed by multiple ways including transconjunctival, transmaxillary, transcranial and eyelid approaches. Presence of multiple splintered intraorbital wooden foreign bodies may further complicate the management. Multiple periorbital surgical exposures may be necessary for the control of foreign body tract. In this case, the wooden foreign body was safely removed by direct surgical exploration of the site using transconjunctival medial anterior orbitotomy. This approach allowed us to reach the deeper areas of intraconal spaces of the medial orbit. In our case, postoperative MRI confirmed complete removal of wooden foreign body. Extraocular muscle function of the patient was normal and no limitations have occurred in the movements of left eye. Wooden foreign bodies degrade easily; therefore, it may not be possible to remove as a single piece. Attention should be given to prevent fragmentation during withdrawal due to liable nature of wooden. In this case, the wooden foreign body was removed in a controlled manner with meticulous hemostasis. Vigorous attempts to remove cause loss 
of hemostasis by disturbing tamponade effect and further damage the globe.

In the management of some orbital lesions, endoscopic orbital surgery instead of conventional orbitotomy techniques was also described. Endoscopic transnasal approach is a technique generally used for resection of orbital tumors located medially and/or inferiorly to the optic nerve. In recent years, several authors have reported successful removal of orbital foreign bodies using endoscopic surgery [10, 11]. Minimally invasive endoscopic surgery has the advantages of minimal surrounding tissue damage and avoiding any further facial scarring. However, the disadvantage of this technique is the risk of inadvertent optic nerve injury [10]. When small intraconal foreign bodies are embedded deep in the orbital fat, endoscopic visualization would be inadequate for accurate localization.

After removal of intraorbital wooden foreign bodies, cultures should be obtained for both bacterial, atypical mycobacterial and fungal pathogens. In this case, S. epidermidis was isolated from wound culture. However, other species such as streptecoccus, E. coli and anaerobes were also encountered from the cases with intraorbital wooden foreign bodies [8]. Therefore, empiric therapy is needed to cover multiple possible organisms. For wooden intraorbital foreign bodies with extension to intraconal area as in our case, it would be more efficient to recommend antibiotics with good blood-brain barrier penetration because of the proximity of the central nervous system and the possibility of infectious spread. It is sometimes impossible to complete initial removal of splintered intraorbital wooden foreign bodies. Even after years of surgery, delayed infectious presentation may occur [12]. To increase success of surgery, careful removal of all fragments, copious irrigation of wound with antibiotic solution and debridement of necrotic tissue are advised.

In conclusion, intraconal wooden foreign bodies require immediate attention and timely management due to severe complications. Furthermore, radiological localization should be ascertained to evaluate the status of surrounding structures and to plan the optimal surgical approach. Transconjunctival anterior orbitotomy can be used as an effective and safe approach for removal of wooden foreign bodies in intraconal orbital space.

\section{References}

1. Tas S, Top H. Intraorbital wooden foreign body: clinical analysis of 32 cases, a 10-year experience. Ulus Travma Acil Cerrahi Derg. 2014;20:51-5.

2. Chen J, Shen T, Wu Y, Yan J. Clinical characeteristics and surgical treatment of intraorbital foreign bodies in a tertiary eye center. J Craniofac Surg. 2015;26:e486-9.

3. Purgason PA, Hornblass A. Complications of surgery for orbital tumors. Ophthal Plast Reconstr Surg. 1992;8:88-93.

4. Di Gaeta A, Giurazza F, Capobianco E, Diano A, Muto M. Intraorbital wooden foreign body detected by computed tomography and magnetic resonance imaging. Neuroradiol J. 2017;30:88-91.

5. John SS, Rehman TA, John D, Raju RS. Missed diagnosis of a wooden intra-orbital foreign body Indian J Ophthalmol. 2008;56:322-4.

6. Dunn IF, Kim DH, Rubin PA, Blinder R, Gates J, Golby AJ Orbitocranial wooden foreign body: a pre-, intra-, and postoperative chronicle: case report. Neurosurgery. 2009;65:E383-4.

7. Siedlecki AN, Tsui E, Deng J, Miller DM. Long-term retention of an intraorbital metallic foreign body adjacent to the optic nerve. Case Rep Ophthalmol Med. 2016;2016:3918592.

8. Shelsta HN, Bilyk JR, Rubin PA, Penne RB, Carrasco JR. Wooden intraorbital foreign body injuries: clinical characteristics and outcomes of 23 patients. Ophthal Plast Reconstr Surg. 2010;26:238-44.

9. Yoshii M, Enoki T, Mizukawa A, Okisaka S. Intraorbital wooden foreign body. Acta Ophthalmol Scand. 2004;82:492-3.
10. Teh D, Mohamad NF, Lim E, Zulkiflee AB, Narayanan P, Kamalden TA. Endoscopic transnasal removal of an intraconal foreign body using an image-guided surgical system. Comput Assist Surg. 2016;21:25-8.

11. Koo Ng NK, Jaberoo MC, Pulido M, Olver JM, Saleh HA. Image guidance removal of a foreign body in the orbital apex. Orbit. 2009;28:404-7.

12. Nishio Y, Hayashi N, Hamada H, Hirashima Y, Endo S. A case of delayed brain abscess due to a retained intracranial wooden foreign body: a case report and review of the last 20 years. Acta Neurochir. 2004;146:847-50 